\title{
PENERAPAN METODE DISCOVERY UNTUK MENINGKATKAN HASIL BELAJAR IPA SISWA KELAS V SDN 006 LANGGINI KABUPATEN KAMPAR
}

\author{
Yenni Fitra Surya \\ Surel: Yenni.fitra13@gmail.com
}

\begin{abstract}
Research background of low learning outcomes of science class $V$ students under the mastery of $85 \%$. The purpose of research to improve learning outcomes. This research is a classroom action research (PTK). The research was conducted in class V SDN 006 Langgini academic year 2016/2017 with total 23 students. Based on the results of the discussion and analysis concluded through the application of discovery method can improve students' science learning outcomes. Increased teacher activity is due to teachers are accustomed to using discovery methods. Student learning outcomes have increased from cycle I to cycle II. Students' learning outcomes before action averaged $57 \%$, then on cycle I get $63 \%$. Cycle II gets an average of $95 \%$.
\end{abstract}

Keywords: Learning Outcomes, Discovery Method, IPA

\begin{abstract}
ABSTRAK
Penelitian dilatarbelakangi rendahnya hasil belajar IPA siswa kelas V di bawah ketuntasan yaitu 85\%. Tujuan penelitian untuk meningkatkan hasil belajar. Penelitian ini merupakan penelitian tindakan kelas (PTK). Penelitian dilaksanakan di kelas V SDN 006 Langgini Tahun Ajaran 2016/2017 dengan jumlah 23 siswa. Berdasarkan hasil pembahasan dan analisis disimpulkan melalui penerapan metode discovery dapat meningkatkan hasil belajar IPA siswa. Meningkatnya aktivitas guru ini disebabkan karena guru sudah terbiasa menggunakan metode discovery. Hasil belajar siswa mengalami peningkatan dari siklus I ke siklus II. Hasil belajar siswa sebelum tindakan rata-rata sebesar 57\%, kemudian pada siklus I mendapatkan 63\%. Siklus II mendapatkan rata-rata $95 \%$.
\end{abstract}

Kata Kunci: Hasil Belajar, Metode Discovery, IPA

\section{PENDAHULUAN}

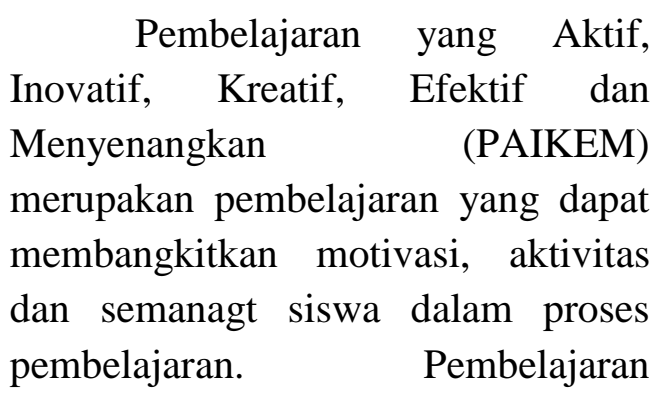

PAIKEM dapat diciptakan oleh guru yang kreatif dan dengan menciptakan bermacam-macam variasi pada proses pembelajaran. Variasi pembelajaran yang dilakukan oleh guru diharapkan dapat meningkatkan motivasi, aktivitas dan hasil belajar siswa dalam

Dosen Universitas Pahlawan Tuanku Tambusai 
proses pembelajaran. Perkembangan kurikulum Ilmu Pengetahuan Alam (IPA) telah merespon secara proaktif sebagai perkembangan informasi, ilmu pengetahuan dan teknologi. Perubahan yang sangat cepat seperti ini merupakan sesuatu hal yang tak dapat dipungkiri lagi. Untuk meningkatkan kemampuan siswa dalam pembelajaran IPA perlu dibekali dengan berbagai kompetensi yang memadai sehingga bisa menjadi siswa yang aktif, kreatif dan mampu mempelajari diri sendiri dan alam sekitarnya. Kemampuan yang diharapkan dapat dimiliki oleh siswa tersebut, sesuai dengan yang dijelaskan dalam kurikulum berbasis kompetensi (2004:3) tentang pembelajaran dibidang IPA sebagai berikut: "IPA berkaitan dengan cara mencari tahu tentang alam secara sistematis, sehingga Sains bukan hanya sekedar penguasaan keterampilan, pengetahuan yang berupa fakta-fakta, konsep-konsep atau prinsip-prinsip saja tetapi juga merupakan proses penemuan".

Dengan melihat pengertian dari IPA di atas, jelaslah bahwa pendidikan IPA menekankan pada pemberian pengalaman langsung dan kegiatan praktis untuk mengembangkan kompetensi agar siswa dapat memahami alam sekitar secara ilmia. Pendidikan IPA diarahkan untuk mencari tahu dan berbuat sehingga dapat membantu siswa untuk memperoleh pengalaman yang lebih mendalam tentang alam sekitar. Idealnya pembelajaran IPA dijadikan sebagai wahana bagi siswa untuk menjadi ilmuwan, terutama siswa Sekolah Dasar (SD). Melalui pembelajaran IPA di sekolah siswa dilatih berfikir, membuat konsep dari pengamatan dan percobaan.

Berdasarkan hal-hal yang dikemukakan di atas tergambar jelas betapa besarnya tugas yang harus diemban oleh guru di Sekolah Dasar. Untuk mewujudkan pembelajaran IPA yang tertuang dalam kurikulum, guru harus bisa menjadi fasilitator dalam pembelajaran dan mampu menciptakan pembelajaran yang sesuai dengan kemampuan dan kebutuhan siswanya. Akan tetapi pada saat sekarang ini masih banyak guru yang belum menguasai kompetensikompetensi yang seharusnya mereka miliki. Hal ini dikemukakan karena masih banyaknya guru-guru mengajar yang masih menggunakan cara lama, yaitu proses pembelajaran satu arah yang didominasi oleh guru melalui metode ceramah. Dalam pembelajaran guru hanya bersikap sebagai pelaksana tugas dan bukan sebagai pemberi pengalaman belajar yang bermakna bagi siswanya. Guru jarang menciptakan model pembelajaran IPA dengan mengadakan pengamatan langsung, percobaan atau simulasi. Berdasarkan hasil pengamatan yang saya lakukan di kelas V SDN 006 Langgini Tahun Ajaran 2016/2017 menunjukkan bahwa pembelajaran IPA masih diajarkan dengan menggunakan 
metode ceramah sebagai metode utama dalam pembelajaran yang kadang-kadang diselingi dengan metode resitasi (pemberian tugas), pada umumnya siswa diminta membaca buku teks dan ditugaskan untuk menjawab soal yang ada di buku teks, hal yang seperti ini menyebabkan siswa hanya bisa menjawab soal yang berbentuk ingatan dan sangat sulit bagi siswa untuk menjawab soal yang bersifat analisis, sehingga pencapaian tujuan pembelajaran IPA yang sesuai dengan kompetensi yang diharuskan oleh kurikulum sangat sulit untuk dicapai.

Untuk mencapai tujuan pembelajaran tersebut, guru tidak seharusnya mendominasi pembelajaran dengan pentransferan ilmu yang ada dalam buku teks melalui metode ceramah saja. Akan tetapi guru harus bisa menjadi fasilitator dalam pembelajaran dengan menggunakan metode yang tepat. Salah satu metode yang bisa digunakan dalam pembelajaran IPA adalah metode discovery. Berdasarkan latar belakang masalah diatas, maka penulis tertarik untuk melakukan penelitian dengan judul "Penerapan Metode Discovery Untuk Meningkatkan Hasil Belajar IPA Pada Materi Gaya Magnet di Kelas V Sekolah Dasar Negeri 006 Langgini”.

Berdasarkan uraian di atas maka dapat dirumuskan masalah sebagai berikut: Apakah Penerapan Metode Discovery Dapat Meningkatkan Hasil Belajar IPAPada
Materi Gaya Magnet Siswa Kelas V Sekolah Dasar Negeri 22 Rimbo Panjang?

Penelitian yang dilaksanakan bertujuan untuk meningkatkan hasil belajar IPA pada materi gaya magnet siswa kelas V Sekolah Dasar Negeri 006 Langgini dengan penerapan mentode discovery.

\section{METODE PENELITIAN}

Jenis penelitian yang dilaksanakan dalam penelitian ini adalah Penelitian Tindakan Kelas (Classroom Action Research). Menurut Arikunto, dkk (2007:58) "Penelitian Tindakan Kelas (PTK) adalah penelitian tindakan (action research) yang dilakukan dengan tujuan memperbaiki mutu pratik pembelajaran di kelasnya".

Penelitian tindakan kelas ini bersifat kolaboratif, maksudnya dalam penelitian ini peneliti bekerjasama dengan rekan sejawat. Rekan sejawat bertindak sebagai observer, yang tugasnya untuk mengamati dan menilai segala aktivitas peneliti selama proses penelitian ini. Penelitian ini dilakukan oleh peneliti yang juga akan bertindak sebagai guru mata pelajaran IPA. Tujuan penelitian ini adalah untuk mengetahui kelemahan dalam proses pembelajaran dan mencari cara untuk mengatasi kelemahan tersebut dan meningkatkan mutu pembelajaran.

Penelitian ini dilakukan dikelas V SDN 006 Langgini dalam dua siklus, satu siklus terdiri dari 2 
pertemuan, daur siklus penelitian tindakan kelas (PTK) menurut Arikunto (2006:16) adalah sebagai berikut :

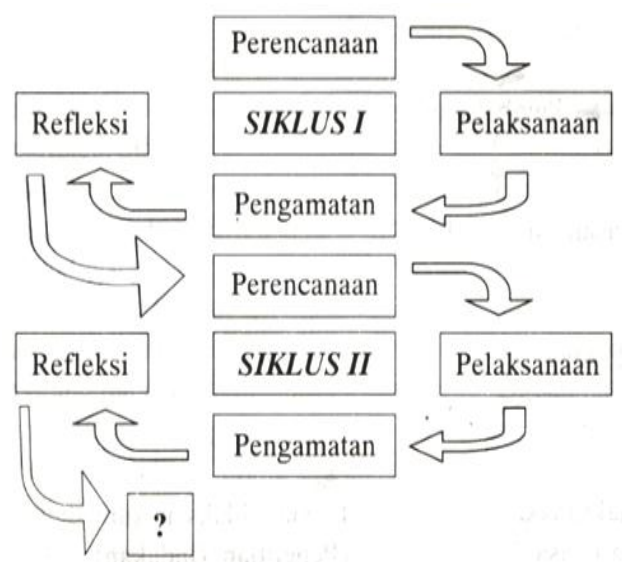

Penelitian ini mengambil lokasi di Sekolah Dasar Negeri 006 Langgini. Sesuai dengan standar kompetensi (SK) dan kompetensi dasar (KD) yang telah ditetapkan oleh pusat, maka penelitian ini akan dilaksanakan pada semester ganjil tahun ajaran 2016/2017. Objek dalam penelitian ini adalah seluruh siswa kelas V Sekolah Dasar Negeri 006Langini yang berjumlah 23 orang siswa terdiri dari 10 orang siswa lakilaki dan 13 orang siswa perempuan.

\section{Kegiatan}

dilaksanakan perencanaan tindakan yang telah ditetapkan, yaitu pembelajaran dilaksanakan sesuai dengan Rencana Pelaksanaan Pembelajaran (RPP) yang telah dibuat. Fokus tindakan pada penelitian ini adalah penggunaan metode discovery yang dioptimalkan untuk meningkatkan pembelajaran IPA. Pada tahap pelaksanaan tindakan ini, proses pembelajaran dilaksanakan dengan menjalankan skenario pembelajaran yang telah dirancang dan terdapat dalam RPP.

\section{HASIL DAN PEMBAHASAN}

\section{Siklus I}

Pada tahap perencanaan peneliti berkolaborasi dengan guru kelas V SDN 006 Langgini membuat persiapan yang terdiri dari rencana pelaksanaan pembelajaran dan lembar tugas siswa. Sedangkan instrumen pengumpulan data yang digunakan dalam penelitian adalah lembar observasi aktivitas guru dan lembar observasi aktivitas siswa dalam pembelajaran. Materi pembelajaran yang dilaksanakan pada pertemuan pertama siklus I adalah pembelajaran sifat-sifat magnet dengan menggunakaan metode discovery. Kompetensi dasar yang ingin dicapai pada materi ini adalah mendiskripsikan hubungan antara gaya, gerak dan energi melalui percobaan (gaya magnet, gaya grafitasi dan gaya gesek).Sedangkan indikator yang ingin dicapai pada siklus 1 ini adalah 1) menyebutkan pengertian magnet, 2) mengidentifikasi benda-benda yang menggunakan magnet dalam kehidupan sehari-hari, 3) mengidentifikasi benda-benda yang dapat ditarik oleh magnet, 4) mengukur kekuatan medan magnet. Untuk mencapai indikator yang telah ditentukan maka disini peneliti selaku praktisi mencoba untuk menggunakan metode discovery dengan mengikuti 
langkah-langkah yang telah ditentukan. Penilaian terhadap pembelajaran di siklus 1 ini adalah dengan melaksanakan evaluasi diakhir pembelajaran pada pertemuan II. Evaluasi tersebut untuk menentukan skor akhir yang diperoleh pada siklus 1 , dan berguna untuk melihat keberhasilan dari siklus 1 ini.

Pelaksanaan pembelajaran siklus 1 ini sesuai dengan rencana yang telah ditetapkan. Pada pertemuan I ini peneliti akan mencoba menyelesaikan indikator yang telah ditetapkan. Berikut kegiatan yang terlaksana pada pertemuan I ini yakni guru bersama siswa mengawali tindakan ini dengan mengucapkan doa sebelum belajar, tindakan dilanjutkan dengan melakukan appersepsi dengan mendekatkan sebuah paku pada sebatang magnet lalu menanyakan kepada siswa tentang pengertian magnet dan dijawab oleh beberapa orang siswa dan jawaban tersebut diberi penguatan.

Guru menjelaskan tentang pengertian magnet dan siswa mendengarkan dengan seksama, salah seorang siswa menanyakan tentang kegunaan magnet dalam kehidupaan sehari-hari, guru tidak langsung menjawab pertanyaan tersebut akan tetapi terlebih dahulu melemparkannya pada semua siswa, beberapa di antara mereka menjawab pertanyaan tersebut sesuai dengan yang diketahuinya dan diberi penguatan. Agar tidak terjadi pemaknaan ganda pada pertanyaan tersebut, guru pun menjawab dan menuliskannya di papan tulis.

Setelah guru selesai menjelaskan pengertian dan kegunaan magnet dalam kehidupan sehari-hari, kegiatan dilanjutkan dengan memancing hipotesa siswa dengan mendekatkan sebuah paku dan pensil pada sebatang magnet, sementara itu siswa disuruh untuk mengamati dengan seksama demonstrasi yang dilakukan. Guru pun mengajukan pertaanyaan kepada siswa "kenapa paku bisa menempel pada magnet sedangkan pensil tidak?", siswa menjawab pertanyaan yang diajukan sesuai dengan pengetahuannya dan diberi penguatan. Langkah selanjutnya adalah membagi siswa menjadi enam kelompok yang heterogen dan terdiri dari 5-6 orang. Sebelum melaksanakan percobaan terlebih dahulu guru menjelaskan tujuan dari percobaan yang dilakukan dan membagikan bahan percobaan kepada setiap kelompok, setiap kelompok mendapatkan bahan percobaan yang sama.

Agar percobaan yang dilakukan oleh siswa bisa berjalan lancar dan sesuai dengan yang diharapkan, gurupun membagikan lembar tugas siswa kepada setiap kelompok yang akan digunakan sebagai panduan dalam melakukan percobaan. Setelah semua bahan dan LTS sudah dibagikan pada semua kelompok, dengan teliti siswa 
membaca dan memahami LTS merekapun mulai melakukan percobaan. Langkah demi langkah mereka kerjakan sesuai dengan LTS, beberapa kelompok menanyakan langkah kerja yang kurang dipahaminya. Setiap pecobaan dilakukan dengan teliti dan hati-hati dalam kelompoknya sementara itu guru mengawasi setiap kelompok dalam melakukan percobaan. Masingmasing notulen ditiap kelompok mencatat hasil pengamatan yang telah didiskusikan dalam kelompoknya dari percobaan yang dilakukan.

Setelah percobaan selesai dilakukan oleh masing-masing kelompok, gurupun meminta salah satu kelompok untuk melaporkannya ke depan kelas, pada awalnya tidak ada kelompok untuk melaporkannya, sampai pada akhirnya guru meminta kelompok I untuk melaporkanhasil diskusinya kedepan kelas. Agar pembelajaran semakin menarik, gurupun menyuruh kelompok lain membandingkan dengan hasil diskusi kelompoknya dan menanggapi laporan hasil diskusi kelompok temannya. Setelah tiga kelompok melaporkan hasil diskusinya kedepan kelas kegiatan dilanjutkan dengan mengadakan diskusi bersama tentang percobaan yang telah dilakukan.

Seluruh alat dan bahan serta

LTS yang digunakan dalam percobaan dikumpulkan ke depan kelas, siswapun dibimbing untuk mengambil kesimpulan dari pembelajaran yang telah dilakukan.
Agar pembelajaran menjadi lebih bermakna dan tahan lebih lama dalam ingataan siswa, gurupun mencatat kesimpulan dari pembelajaran yang telah dilakukan di papan tulis, pembelajaran ditutup dengan mengucapkan Hamdalah.

Berdasarkan hasil observasi yang dilakukan guru kelas dan teman sejawat pada siklus I ini praktisi telah melaksanakan pembelajaran yaitu dari segi guru kurang bisa memotivasi anggota tiap-tiap kelompok untuk bisa aktif melakukan percobaan bersama teman-temaan dalam kelompoknya, sehingga kelompok yang dibentuk secara heterogen belum bisa membentuk kerja sama yang baik. Dalam memimpin diskusi kelas untuk menyimpulkan pelajara guru kurang bisa menjadi seorang moderator yang baik sehingga diskusi tidak berjalan dengan baik dan hanya dua kelompok yang aktif melakukan tannya jawab.Dari segi siswa yaitu siswa mendengarkan penjelasan guru tentang materi dengan baik namun beberapa siswa tidak aktif dalam melaksanakann percobaan dan pasif dalam berdiskusi dan ada beberapa kelompok yang tidak mau melaporkan hasil diskusinya.

Kegiatan refleksi dilakukan secara kolaboratif antara praktisi dan guru kelas (observer) pada setiap pembelajaran berakhir. Pada kesempatan ini temuan dan hasil pengamatan peneliti dibahas bersama. Refleksi tindakan siklus I ini mencakup refleksi terhadap 
perencanaan, pelaksanaan, evaluasi dan hasil yang diperoleh oleh siswa. Keberhasilan guru pada pertemuan pertama siklus I, penyampaian materi dilakukaan dengan baik, langkahlangkah pembelajaran sudah dilakukan sesuai dengan rencana pembelajaran, sudah sebagian siswa yang terdorong untuk melaksanakan percobaan dengan baik dalam kelompoknya. Keberhasilan siswa diantaranya siswa mengikuti pembelajaran dengan antusias walau masih ada yang bermain dan tidak serius, siswa melakukan percobaan dengan teliti dan seksama dalam kelompoknya. Kendala yang dihadapi yaitu penggunaan waktu belum maksimal dan belum sesuai dengan rencana yang telaah ditentukaan dalaam Rencana Pelaksanaan Pembelajaraan (RPP), manajemen kelas kurang baik, sehingga masih ada siswa yang tidak memperhatikan guru sewaktu menjelaskan materi, belum seluruh anggota kelompok aktif melakukan percobaan dalam kelompoknya, belum adanya kepercayaan diri siswa untuk maju ke depan kelas.

\section{Siklus II}

Hasil analisis refleksi pada siklus I pada pertemuan pertama dan kedua menunjukkan subjek penelitian belum mencapai tujuan pembelajaran khususnya yang diharapkan. Karena itu pembelajaran dilanjutkan dengan siklus II. Pembelajaran siklus II diberikan agar siswa dapat memahami lebih lanjut materi yang diberikan guru yakni tentang materi magnet alam dan magnet buatan, dengan indikator 1) membedakan antara magnet alam dan magnet buatan. 2) membuat magnet buatan secara induksi, 3) membuat magnet buatan dengan menggunakan aliran listrik, 4) membuat magnet buatan dengan cara gesekan. Pembelajaran siklus II dilaksanakan dalam dua pertemuan. Pada siklus II ini, siswa yang mengikuti sama dengan siklus I yakni sebanyak 23 orang dimana perempuan 17 orang dan 11 laki-laki. Pada siklus II ini, peneliti kembali membuat Rencana Pelaksanaan Pembelajaran. Berdasarkan hasil tindakan dari siklus I yang telah diuraikan diatas maka pada siklus II ini tindakan yang akan dilaksanakan yakni: 1) memperbaiki cara pembagian kelompok dengan cara mengurutkan siswa berdasarkan skor dasar yang telah ada. 2) merancang LKS yang mudah dipahami bahasanya oleh siswa sehingga siiswa tiidak ragu dalam melaksanakan percobaan. 3) berusaha memaksimalkan pemakaian waktu dalam pembelajaran sesuai dengan rencana pembelajaran. 4) Memperbaiki cara memotivasi siswa agar dapat ikut aktif dalam melakukan percobaan dengan memberikan semangat dan dorongan, 5) Memperbaiki langkah-langkah yang tumpang tindih antara kegiatan membagi kelompok dengan menyampaikan materi. Untuk siklus 
II ini, peneliti berencana mendahulukan menyampaikan materi barulah membagi kelompok.

\section{Peneliti}

memulai

pembelajaran dengan mengucapkan salam dan menyampaikan materi yang akan dipelajari yaitu mengenai magnet alam dan magnet buatan. Dengan indikator yang telah ditentukan pada tahap perencanaan. Selanjutnya peneliti menyampaikan tujuan yang akan dicapai. Pada tahap ini, peneliti melaksanakan tindakan berdasarkan apa yang telah direncanakan. Tindakan yang peneliti lakukan mencakup kegiatan sebagai berikut: 1) Guru mengawali dengan salam seperti biasa. 2) Guru mencoba menyampaikan materi dengan jelas dan runtut sebelum membagi kelompok. 3) Guru membagi siswa dalam kelompok, 4) Guru menyampaikan permasalahan yang akan didiskusikan dengan jelas serta membagikan LTS terhadap siswa. 5) guru memberikan kesempatan kepada kelompok untuk menanyakan langkah kerja yang terdapat dalam LTS yang kurang dipahami. 6) guru menunjuk kelompok dengan nomor acak untuk melaporkan ke depan kelas. Hal ini dilakukan dengan cara memberikan motivasi kepada setiap kelompok agar mau melaporkan ke depan kelas. 7) Guru memberikan evaluasi terhadap siswa secara individu. Dan pembelajaran ditutup dengan menyimpulkan pembelajaran serta pemberian penghargaan oleh guru terhadap siswa yang memperoleh nilai yang bagus.

Sebagaimana halnya siklus I, pembelajaran siklus II juga diamati bahwa penelitian dalam pembelajaran siklus II telah melaksanakan tugas dengan baik. Dari hasil temuan kolaborator dan peneliti adalah sebagai berikut, dari segi guru yaitu waktu sudah dapat dimanfaatkan dengan baik. Mulai dari awal pelajaran sampai akhir pelajaran. Begitu pula dengan percobaan yang dilakukan oleh siswa. b) keaktifan siswa sudah terlihat dan teratur. Semua siswa nampak antusias dalam melakukan percobaan dalam kelompoknya. c) siswa sudah memahami percobaan yang mereka lakukan. Hal ini dibuktikan dengan setiap siswa yang ditunjuk untuk melaporkan ke depan kelas mau melaksanakannya dengan baik. Dari segi siswa yaitu siswa terlihat antusias dalam melaksanakan percobaan yang dilakukan dalam kelompoknya. b) siswa yang terpanggil ke depan kelas sudah bersedia untuk melaporkan hasil percobaan yang mereka diskusikan dalam kelompoknya. c) hasil diskusi siswa sudah mulai terlihat dengan baik, d) evaluasi yang diikuti siswa menampakkan siswa paham dengan percobaan yang mereka lakukan. Hal ini terbukti dengan meningkatnya hasil evaluasi individual siswa.

Kegiatan refleksi dilakukan secara kolaboratif antara praktisi dan guru kelas (observer) pada setiap 
pembelajaran berakhir. Pada kesempatan ini temuan dan hasil pengamatan peneliti dibahas bersama. Refleksi tindakan siklus I ini mencakup refleksi terhadap perencanaan, pelaksanaan, evaluasi dan hasil yang diperoleh oleh siswa. Keberhasilan guru pada pertemuan pertama siklus I, Keberhasilan guru yaitu guru sudah lebih leluasa menyampaikan dan menggunakan langkah-langkah dalam pembelajaran, penggunaan waktu dalam pembelajaran pun sudah maksimal, Setiap kelompok dapat dibimbing dengan baik. Keberhasilan siswa yaitu keaktifan siswa sudah terlihat dengan baik dalam melakukan percobaan dalam kelompoknya. Siswa yang ditunjuk bersedia dengan senang hati untuk tampil ke depan kelas melaporkan hasil percobaanya. Nilai yang didapat siswa sudah menampakkan hasil yang memuaskan, baik nilai diskusi kelompok maupun hasil evaluasi serta ketuntasan belajar siswa.

Pembahasan

Pelaksanaan pembelajaran yang aktif dan menyenangkan sangat dibutuhkan oleh siswa Sekolah Dasar (SD), karena dapat mempermudah siswa untuk memahami materi dengan cepat.

Berdasarkan hasil catatan lapangan dan diskusi peneliti dengan teman kolaborator diatas, penyebab dari adanya siswa yang belum dapat memahami materi dengan baik. Dari analisis penelitian siklus I nilai ratarata kelas baru mencapai 5,43. Berdasarkan hasil pengamatan siklus I yang diperoleh maka direncanakan untuk melakukan siklus II. Guru harus dapat memperhatikan perbedaan yang ada pada siswa karena tiap individu mempunyai karakteristik yang berbeda. Menurut Rochman Natawijaya (dalam Rosna, 2006:43) "Belajar adalah proses pembinaan yang terus menerus terjadi dalam diri individu yang tidak ditentukan oleh unsur keturunan, tetapi lebih banyak ditentukan oleh faktor-faktor dari luar anak." Dalam belajar siswa banyak memperoleh dari guru, maka guru harus lebih memahami kembali ketiga aspek dalam pendidikan yaitu yang belajar, proses belajar dan situasi belajar. Yang belajar adalah anak didik atau siswa yang secara individu atau kelompok mengikuti proses pembelajaran dalam suasana tertentu.

Guru sebagai penggerak dan pengatur proses pembelajaran sudah seharusnya dapat mengaktifkan semua siswa tanpa terkecuali agar potensi yang ada pada siswa dapat tergali dan berkembang. Guru harus dapat memberikan motivasi kepada siswa dalam pembelajaran. Peran guru dalam membelajarkan siswa sangat besar, upaya menimbulkan motivasi siswa untuk belajar.

Pembelajaran magnet alam dan magnet buatan yang dilaksanakan pada siklus II ini sudah berjalan dengan baik, walau masih ada 
beberapa orang siswa yang belum dapat menyelesaikan evaluasi yang diberikan dengan baik. Cara guru dalam membimbing siswa untuk melakukan percoobaan sudah cukup baik. Begitu juga dalam hal menunjuk siswa untuk melaporkan hasil diskusi ke depan kelas, juga sudah merata di seluruh siswa. Dari hasil analisis penelitian siklus II sudah mencapai $84 \%$ dan nilai rata-rata kelas 8.4. Berdasarkan hasil pengamatan siklus II yang diperoleh maka pelaksanaan siklus II sudah baik dan guru sudah berhasil dalam usaha peningkatan hasil belajar siswa dalam pembelajaran sifat-sifat gaya magnet dengan menggunakaan metode discovery bagi siswa kelas IV SDN 008 Langgini Kabupaten Kampar.

Pembelajaran yang disajikan guru pada siklus II guru dalam memberikan simultan sangat bagus. Apalagi dengan guru menggunakan metode discovery ini dimana metode ini mendoorong semaangat siswa untuk menemukan dan membuktikan sendiri tentang permasalahan yang diiajukan.

Selain itu, guru juga harus meberi kesempatan kepada siswa untuk bekerja dalam kelompoknya dan bertanya tentang langkah kerja dalam LTS tidak dimengerti oleh siswa. Untuk itu guru harus mampu menciptakan situasi yang menyenangkan untuk belajar. Untuk mencapai hal tersebut sudah seharusnya guru mampu menciptakan pembelajaran yang sesuai dengan kebutuhan siswa. Selain itu, guru juga harus memperhatikan keberhasilan siswa dalam memahami sesuatu dengan cara sesuai dengan tingkat kemampuan siswa. Karena guru bertugas membelajarkan siswa. Untuk membelajarkan siswa tersebut guru haruslah menggunakan berbagai macam cara agar pembelajaran dapat bermakna bagi siswa, seperti menggunakan metode, pendekatan dan model dalam pembelajaran yang bervariasi, media pembelajaran yang sesuai dengan tujuan dan menciptakan suasana belajar yang menyenangkan bagi siswa.

\section{SIMPULAN}

Berdasarkan hasil analisis dan pembahasan di atas, maka peneliti dapat menarik kesimpulan dari penelitian ini yakni: Pembelajaran dengan menggunakan metode discovery dapat meningkatkan hasil belajar siswa. Selain itu, siswa juga menjadi lebih aktif dalam belajar.

Hal itu dapat terlaksana karena permasalahan yang diajukan sering mereka temui dalam kehidupan sehari-hari, berakibat siswa termotivasi untuk aktif melakukan percobaan dalam kelompoknya. Dengan menggunakan metode ini, siswa sudah mulai cenderung untuk aktif dalam pembelajaran. Apalagi dengan menggunakan metode discovery ini, nantinya guru akan memberikan penghargaan kepada kelompok yang memperoleh nilai yang tertinggi. Meningkatnya hasil 
belajar siswa tersebut dapat dilihat dari rata-rata yang diperoleh pada siklus I yakni 5,4 dan mengalami peningkatan pada siklus II yakni 8,4 . hal ini merupakan bukti keberhasilan pelaksanaan penelitian yang telah dilakukan di kelas V SDN 008 Langgini Kabupaten Kampar.

DAFTAR RUJUKAN

Arikunto. (2006). Penelitian Tindakan Kelas. Jakarta: Bumi Aksara.

Abu Ahmadi, Joko Tri Prasetyo. (2005). Strategi Belajar Mengajar. Bandung: Pustaka Setia.

Depdiknas. (2006). Kurikulum Tingkat Satuan Pendidikan. Jakarta: Dirjen Pendidikan Tinggi.

Depdiknas. (2004). Kurikulum Berbasia Kompetensi. Jakarta: Dirjen Pendidikan Tinggi.

Maslichah asy'ari. (2006). Penerapan Pendekatan Sains-TeknologiMasyarakat Dalam Pembelajaran Sains Di Sekolah Dasar. Yogyakarta: Pustaka Setia.

M. Ngalim Purwanto. (1996). Psikologi Pendidikan. Bandung: $\quad$ CV Sinar Bandung.
Nana Sudjana. (1989). Dasar-Dasar Proses Belajar Mengajar. Jakarta: Sinar Baru Algesindo.

Oemar Hamalik. (2004). Pendidikaan Guru Berdasarkan Pendekatan Kompetensi. Jakarta: PT Bumi Aksara.

Ritawati Mahyudin, Yetti Ariani.(2007). Hand Out Mata Kuliah Metodologo Penelitian Tindakan Kelas. Padang: FIP.

Roestiyah N.K. (2001). Strategi Belajar Mengajar. Jakarta: PT Rineka Cipta.

Santi Dewiki, Sri Yuniati. (2006). Ilmu Alamiah Dasar. Jakarta: Universitas Terbuka.

Wardani. (2007). Penelitian Tindakan Kelas. Jakarta. UT. 